\title{
EXPLORATION AND COLLECTION OF RARE Helianthus SPECIES FROM SOUTHEASTERN UNITED STATES
}

\author{
Gulya, T.J. $^{1^{*}}$, Seiler, G.J. ${ }^{1}$, Kong, G. $^{2}$ and Marek, L.F. ${ }^{3}$ \\ ${ }^{1}$ USDA-ARS Sunflower Research Unit, Fargo, ND 58105, USA \\ ${ }^{2}$ Dept. Primary Industries, Toowoomba, $4350 \mathrm{QLD}, A U$ \\ ${ }^{3}$ USDA-ARS-NCR Plant Introduction Station, Ames, IA 50011, USA
}

Received: March 10, 2007

Accepted: June 25, 2007

\section{SUMMARY}

A 10-day trip, encompassing $4600 \mathrm{~km}$ in the southeastern USA states of Tennessee, North Carolina, South Carolina, Georgia and Alabama, was made in October, 2003. Our primary objective was to locate populations of Helianthus eggertii, then on the USDI, Fish and Wildlife Service Threatened and Endangered Species list, and $H$. verticillatus, a candidate for endangered species status. Helianthus eggertii has since been de-listed (August 2005). An additional objective was to collect seeds of $H$. porteri, a species reclassified from Viguiera porteri, which is endemic to granite rock outcrops in Georgia. We collected seeds from 27 populations of the above three species plus three additional species, $H$. angustifolius, $H$. atrorubens, and $H$. smithii. Seed was deposited with the USDA-ARS North Central Regional Plant Introduction Station at Ames, Iowa (NCRPIS) from which 24 of the 27 collections are available for distribution. The three 'target' species were represented by 13 collections of $H$. eggertii, eight of $H$. porteri, and two of $H$. verticillatus; none of the three species were previously available from the NCRPIS sunflower collection. The availability of seed of these three species will allow researchers around the world the opportunity to investigate the potential of these wild Helianthus species to contribute useful traits to cultivated sunflower. Complete collection data has been loaded into the USDA-ARS Germplasm Resource Information Network (GRIN), and is available on the internet (www.ars-grin.gov).

Key words: $\quad$ sunflower, wild Helianthus species, germplasm collection, $\boldsymbol{H}$. eggertii, $\boldsymbol{H}$. verticillatus, $\boldsymbol{H}$. porteri, southeastern USA states

\section{INTRODUCTION}

The USDA-ARS wild Helianthus germplasm collection, housed in the USDAARS North Central Regional Plant Introduction Station (NCRPIS) in Ames, Iowa, currently manages 2022 accessions of wild Helianthus species, of which 1584 are

* Corresponding author 
available for distribution. Of 23 annual and 43 perennial Helianthus taxa, four are not currently represented in the collection [H. niveus ssp. niveus, H. laciniatus, $H$. multiflorus, and $H$. nuttallii ssp. parishii]. Six taxa have only one or two accessions and six taxa have no accessions with distributable seed (Table 1). Of the four taxa without representation in the NCRPIS collection, one is likely extinct ( $H$. nuttallii ssp. parishii) and one, endemic to Pacific coast regions of Baja California, Mexico (H. niveus ssp. niveus) is unobtainable at this time due to international germplasm issues. The USDA-ARS Sunflower Unit in Fargo, North Dakota, has recently increased its efforts to collect seed of these underrepresented species by conducting annual exploration trips to various parts of the US.

The objective of this trip to five southeastern states (Tennessee, North Carolina, South Carolina, Georgia and Alabama) was to collect seeds of three rare Helianthus species. Helianthus eggertii is a perennial species found only in Tennessee (15 counties), Kentucky (9 counties) and Alabama ( 3 counties) in barren forest openings, typically created by fire (Jones, 1994). This species had only two accessions in the NCRPIS seedbank, neither of which was available for distribution. $H$. eggertii was listed as an endangered species by the USDA, Fish and Wildlife Service (USFWS) from 1997 until August 2005 when it was de-listed (White and Ratzlaff, 1999). The USFWS shared site information for over 200 populations with our unit. Helianthus porteri (commonly known as the 'Confederate daisy'), reclassified from the genus Viguiera (Pruski, 1998) is confined to barren, granite outcrops such as Stone Mountain, GA. The distribution of these granite outcrops is limited to the Piedmont region of Georgia, South Carolina and North Carolina. There were no accessions of this species in any USDA-ARS germplasm collection. Helianthus verticillatus was first collected in Tennessee in 1892 (Small, 1898) and was not observed again until1994 (Matthews et al., 2002). It is currently known from fewer than ten populations in northwestern Georgia, northeastern Alabama and western Tennessee. Helianthus verticillatus is a low priority candidate for federal protection, and there were no accessions in the USDA-ARS seed collection prior to this collection trip. In addition to the above species of high collection priority, this area of the US was within the range of at least 27 other Helianthus taxa (Rogers et al., 1982; Weakley, 2006), making the region extremely rich in species diversity.

\section{MATERIALS AND METHODS}

Since two of the target species ( $H$. eggertii and $H$. verticillatus) are currently being monitored by state and federal agencies, there are reports documenting sites of current populations for these three species. Thus, for H. eggertii, there are 128 populations monitored by the USFWS and the Tennessee Natural Heritage Program (White \& Ratzlaff, 1999), as well as several dozen sites on the Arnold Air Force Base (central TN), monitored by the US Air Force and contract botanists. Helianthus verticillatus populations are being monitored by the Alabama and Georgia Natural 
Table 1: Wild Helianthus species seed availability in the USDA-ARS NCR Plant Introduction collection as of December, 2006.

\begin{tabular}{|c|c|c|c|c|c|}
\hline Annual Species & Total & Avail & Perennial Species & Total & Avail \\
\hline H. annuus & 874 & 850 & H. angustifolius & 19 & 6 \\
\hline H. agrestis & 5 & 0 & H. arizonensis & 2 & 0 \\
\hline H. anomalus & 8 & 4 & H. atrorubens & 14 & 8 \\
\hline H. argophyllus & 46 & 20 & H. californicus & 21 & 18 \\
\hline H. bolanderi & 8 & 6 & H. carnosus & 3 & 0 \\
\hline H. debilis ssp. cucumerifolius & 7 & 7 & H. ciliaris & 6 & 2 \\
\hline H. debilis ssp. debilis & 13 & 12 & H. cusickii & 21 & 12 \\
\hline H. debilis ssp. silvestris & 22 & 22 & H. decapetalus & 31 & 21 \\
\hline H. debilis ssp. tardiflorus & 5 & 5 & H. divaricatus & 33 & 9 \\
\hline H. debilis ssp. vestitus & 3 & 3 & H. eggertii & 15 & 10 \\
\hline H. exilis & 28 & 20 & H. floridanus & 4 & 2 \\
\hline H. deserticola & 22 & 15 & H. giganteus & 29 & 15 \\
\hline H. neglectus & 28 & 28 & H. glaucophyllus & 1 & 0 \\
\hline H. niveus ssp. canescens & 19 & 13 & H. gracilentus & 7 & 5 \\
\hline H. niveus ssp. niveus & 0 & 0 & H. grosseserratus & 44 & 39 \\
\hline H. niveus ssp. tephrodes & 12 & 6 & H. heterophyllus & 8 & 0 \\
\hline H. paradoxus & 10 & 0 & H. hirsutus & 18 & 5 \\
\hline H. petiolaris ssp. fallax & 35 & 35 & H. laciniatus & 0 & 0 \\
\hline H. petiolaris ssp. petiolaris & 102 & 100 & H. laetiflorus & 7 & 2 \\
\hline H. porteri & 8 & 8 & H. laevigatus & 6 & 2 \\
\hline H. praecox ssp. hirtus & 7 & 7 & H. longifolius & 2 & 2 \\
\hline H. praecox ssp. praecox & 9 & 9 & H. maximiliani & 65 & 53 \\
\hline \multirow[t]{20}{*}{ H. praecox ssp. runyonii } & 25 & 25 & H. microcephalus & 11 & 4 \\
\hline & & & H. mollis & 26 & 11 \\
\hline & & & H. multiflorus & 0 & 0 \\
\hline & & & H. nuttallii ssp. nuttallii & 26 & 23 \\
\hline & & & H. nuttallii ssp. parishii & 0 & 0 \\
\hline & & & H. nuttallii ssp. rydbergii & 16 & 16 \\
\hline & & & H. occidentalis ssp. occidentalis & 1 & 1 \\
\hline & & & H. occidentalis ssp. plantagineus & 11 & 8 \\
\hline & & & H. pauciflorus ssp. pauciflorus & 8 & 5 \\
\hline & & & H. pauciflorus ssp. subrhomboideus & 16 & 11 \\
\hline & & & H. pumilus & 51 & 44 \\
\hline & & & H. radula & 16 & 3 \\
\hline & & & H. resinosus & 18 & 5 \\
\hline & & & H. salicifolius & 1 & 0 \\
\hline & & & H. silphioides & 2 & 1 \\
\hline & & & H. simulans & 3 & 2 \\
\hline & & & H. smithii & 6 & 4 \\
\hline & & & H. strumosus & 34 & 15 \\
\hline & & & H. tuberosus & 107 & 22 \\
\hline & & & H. verticillatus & 2 & 2 \\
\hline
\end{tabular}


Heritage Program. Several of the larger populations occur within a conservation easement donated by the Temple-Inland Timber Corporation to the Nature Conservancy. Helianthus porteri is endemic to granite outcrops in the Piedmont area of northern Georgia, with lesser occurrences in northern Alabama and South Carolina (McVaugh, 1943). The Georgia Natural Heritage Program, which graciously supplied us with site location information, monitors the species.

Since the above three Helianthus species have been extensively monitored by several state and federal agencies, there was a considerable amount of information available about their specific occurrences, despite the fact that populations of each species are limited. In addition to utilizing these data, we also relied heavily upon the expertise and personal involvement of several local botanists, who are listed in the acknowledgements. Once a Helianthus population was physically located, the GPS coordinates were determined with a Garmin III Plus GPS receiver and the site marked on a computer-based topographic map (iGage "All Topo"). Seed was collected from as many mature heads and plants as possible, and information on site habitat, plant morphology, and phenology recorded. Digital photographs were taken at all sites, as well as a pressed plant specimen for the USDA-ARS Sunflower Unit herbarium in Fargo, ND. More detailed description of preparations and conduct of these collecting trips have been published (Seiler and Gulya, 2004).

Seeds were processed and inventoried by personnel at the USDA-ARS NCRPIS (Ames, IA) and information entered into the National Plant Germplasm System (NPGS) Germplasm Resources Information Network (GRIN) database. Thus, complete information on all collections, including collection site and evaluation data, are available through the GRIN database (http://www.ars-grin.gov/cgi-bin/npgs/html/ tax_search.pl?Helianthus). The collection site map (Figure 1) was created using Arc-GIS 9.0 software (ESRI 2004).

\section{RESULTS AND DISCUSSION}

A total of 27 populations of the three target species, plus three other Helianthus species, were located and seeds collected during the October, 2003 trip (Table 2). Seeds were collected from 13 populations of $H$. eggertii in $\mathrm{AL}, \mathrm{SC}$ and TN, eight populations of $H$. porteri in GA and NC, two populations of $H$. verticillatus in TN and AL, plus two populations of $H$. angustifolius (GA and TN) and one each of H. atrorubens (AL) and H. smithii (NC) (Figure 1).

Helianthus eggertii is a perennial, rhizatomous, hexaploid species found primarily in forest openings in central Tennessee, central Kentucky, and northern Alabama (Figure 2). The species is tall (up to $2.5 \mathrm{~m}$ ), has distinctive purple, glabrous, waxy stems, nearly sessile single-veined leaves, and blooms from early August through mid-September (Rogers et al., 1982; Schilling, 2006). We made 13 collections of $H$. eggertii primarily from TN (10), with five of those collected on the grounds of the Arnold Engineering Development Center (AEDC) in central TN. This 


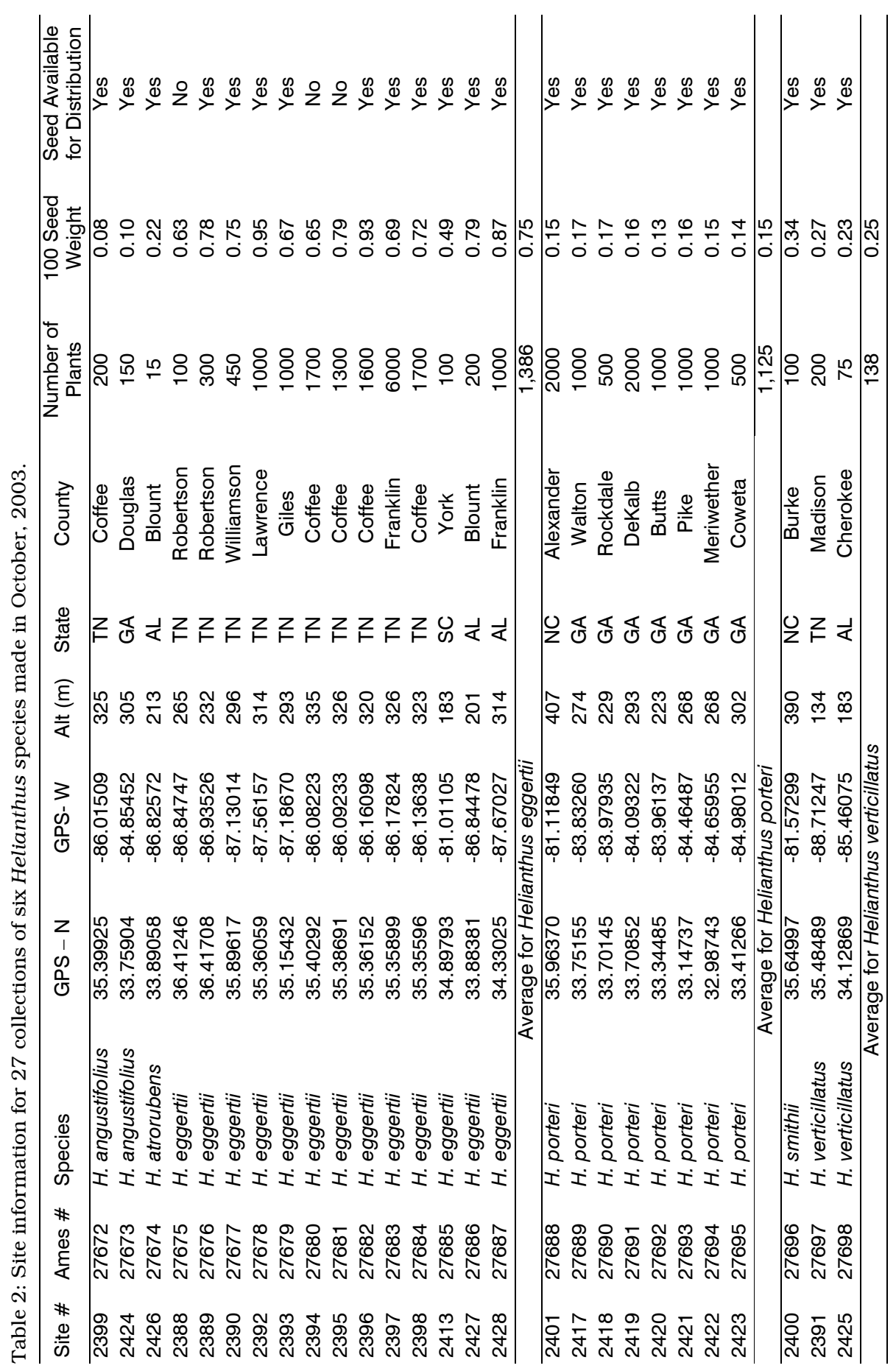




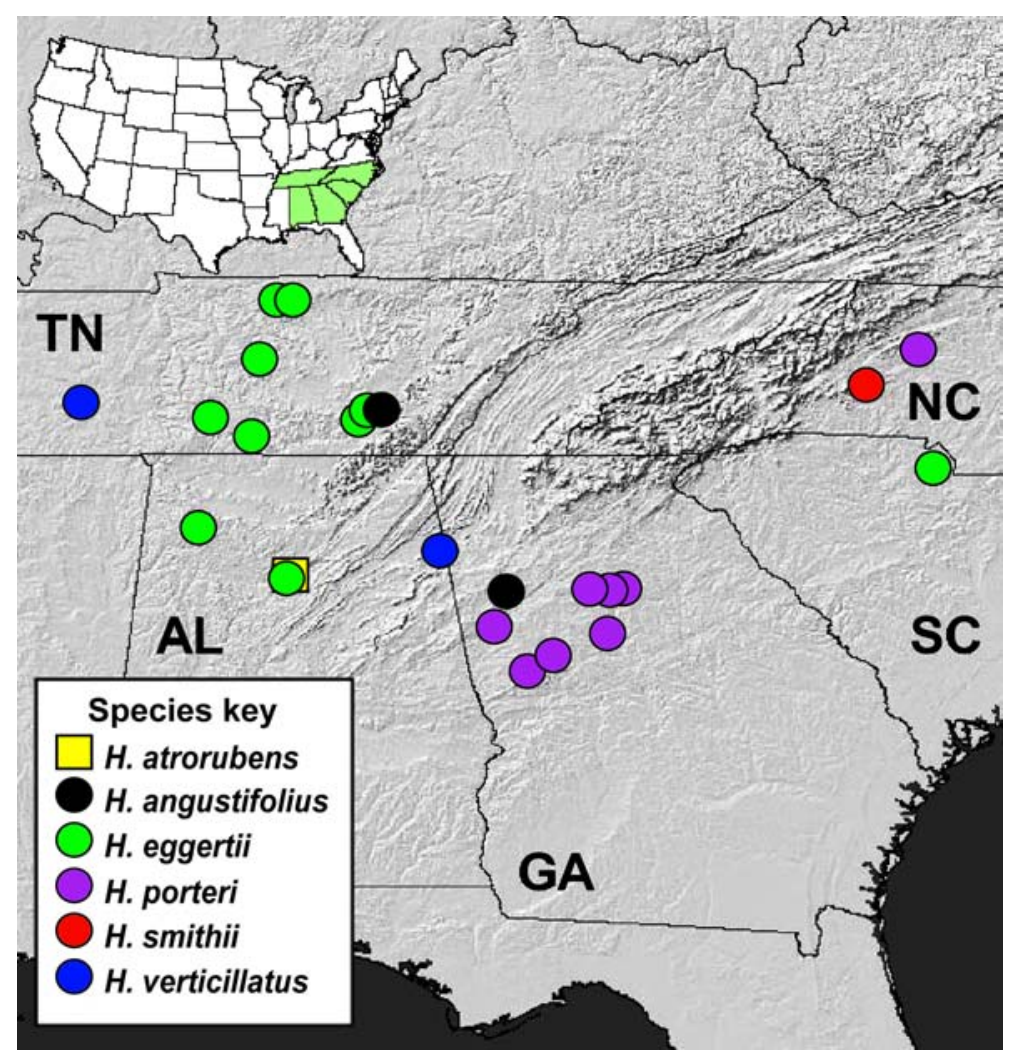

Figure 1: Location of 27 sites in southeastern United States where collections of six Helianthus species (H. angustifolius, H. atrorubens, H. eggertii, H. porteri, H. smithii, and $H$. verticillatus) were made during the October, 2003 trip. (Map created using Arc-GIS 9.0 software (ESRI 2004). Copyright @ 2004 ESRI, data layers from ESRI and USGS. All rights reserved.)

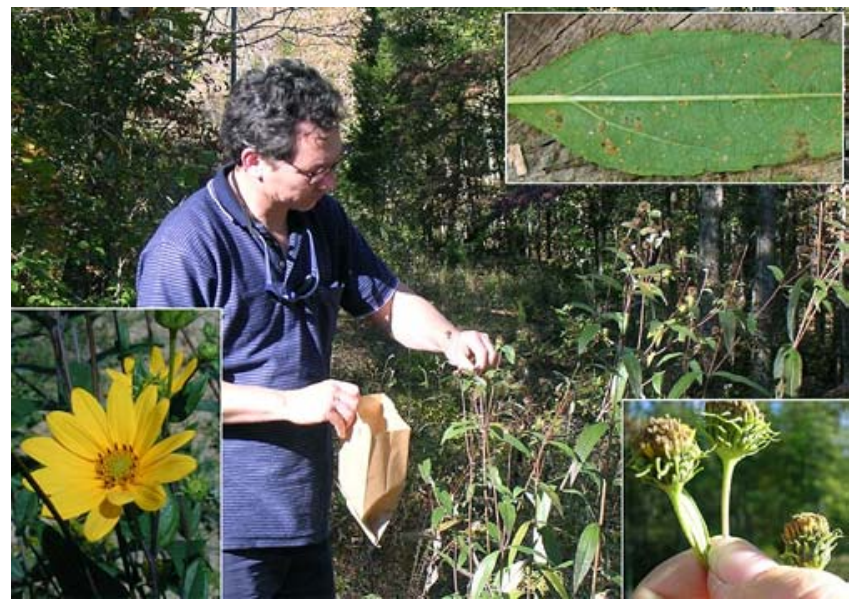

Figure 2: Gary Kong harvesting seed heads of Helianthus eggertii in a typical forest clearing habitat of central Tennessee. Note purple stems and top branching. Flower head, with purple stems (lower left), mature heads (lower right) and leaf underside (upper right) with orange pustules of Coleosporium helianthi rust. 
latter site is owned by the US Air Force and the $H$. eggertii sites are managed by prescribed burns by base personnel. The other collections were from AL (2) and SC (1). Population sizes varied from $\sim 100$ plants to several thousand (as documented by AEDC surveys). The 13 collections span a significant portion of the geographic distribution of $H$. eggertii and presumably capture a wide genetic diversity. Enough seed was collected to make nine of the 13 available for distribution (Table 2). Helianthus eggertii is also reported in at least 11 counties of Kentucky, but no sites in KY were visited during this trip. Helianthus eggertii seeds were the largest of any species collected during the trip, averaging $0.75 \mathrm{~g} / 100$ seeds. Seeds of all the other collected species averaged $0.26 \mathrm{~g} / 100$ seeds or less.

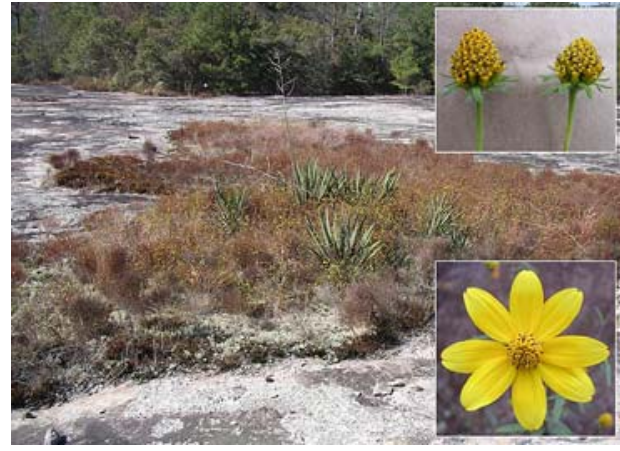

Figure 3: Typical granite rock outcrop site for Helianthus porteri in northern Georgia, showing "islands" of vegetation in shallow depressions. Upper right insert shows conical form of mature seed heads, and lower right insert shows flower in bloom, with notched ray petals.

Figure 4: Helianthus verticillatus, in western Tennessee, showing tall nature ( $\sim 4$ meters) of mature plant relative to Claude Bailey (left) and Gerald Seiler (right). Bottom left insert shows whorled leaf arrangement, and upper right insert depicts flower in full bloom.

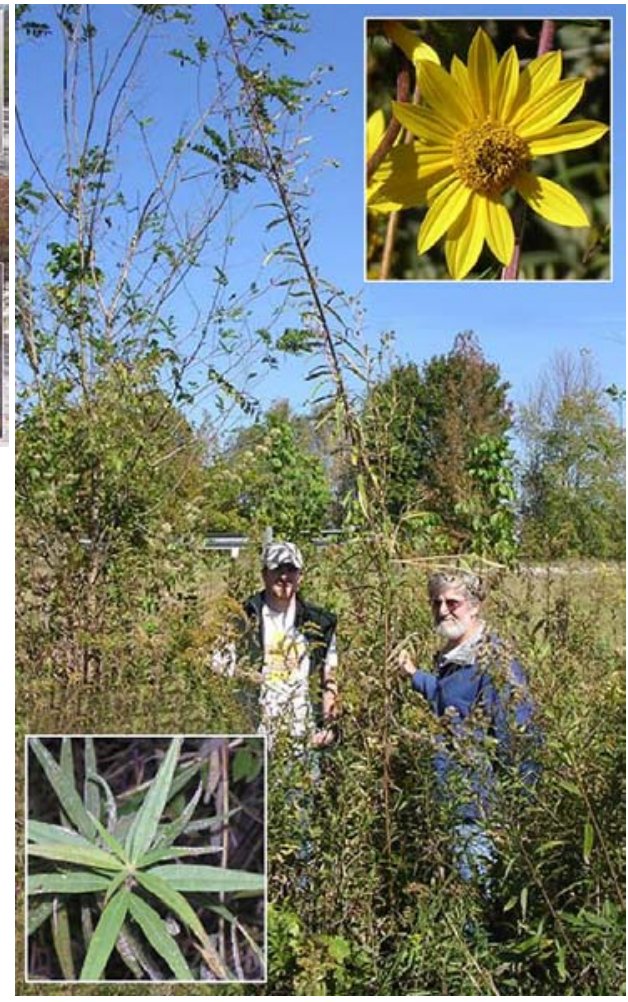

Helianthus porteri is an annual, diploid species characterized by small, conical heads and long, narrow leaves on basally branched plants up to $1 \mathrm{~m}$ in height (Rogers et al., 1982; Schilling, 2006). Collection sites for H. porteri were all granite rock outcrops, and all but one was in Georgia, although the species is also found in AL, NC and SC (Figure 3). This habitat is unique, consisting of "islands" of vegetation a few meters wide occurring in shallow depressions on the otherwise barren rock surface. Mosses, lichens, and bryophytes initially colonize these islands, and when enough organic matter accumulates, larger successional plants are found. Plant 
species associated with $H$. porteri in these granite outcrops include: Agrostis elliottiana (bentgrass), Arenaria brevifolia (sandwort), Bulbostylis capillaris (tufted sedge), Sedum smallii, Hypericum gentianoides (pineweed), and Minuartia uniflora (oneflower stitchwort) (Murdy and Carter, 2000). H. porteri, along with S. smallii and M. unifloria, are considered the dominant annual forbs in these habitats (Shure and Ragsdale, 1977). Population size of $H$. porteri at each site varied from $\sim 500$ to nearly 2000 plants. The one $H$. porteri site at Rocky Face (Alexander County), NC is not a natural occurrence, but was planted as part of an ecological study (Mellinger, 1972) and has since become established. The greatest concentration of granite outcrops, and thus sites for $H$. porteri, is in GA, with fewer sites in $\mathrm{AL}$ and SC (McVaugh, 1943). The species is extremely floriferous and productive. Seed size, at $0.15 \mathrm{~g} / 100$ seeds, was the smallest of any species collected on this trip. Since there were no previous accessions of $H$. porteri in any USDA-ARS seedbank, the eight collections made on this trip comprise the entire array of available germplasm.

Helianthus verticillatus is a robust (up to $4 \mathrm{~m}$ in height) diploid perennial species, characterized by its unique verticillate leaf arrangement in whorls of three and sometimes four (Figure 4) (Matthews et al., 2002). Helianthus verticillatus is currently known from only two areas: Madison County in western TN and the Coosa River valley, straddling the Alabama-Georgia border (325 km from the TN area). The Coosa River valley area encompasses Cherokee County in AL and Floyd County in GA, but the populations in these counties are reported to be $<5 \mathrm{~km}$ apart. Plant population size was modest at both locations, ranging from 100 to 200 plants. The Coosa River valley area contains several known locations of this species, most of which are on private land. One such concentration is on land owned by a timber company, and the Nature Conservancy has obtained a "conservation easement" ensuring protection of all rare species on a 375 ha tract of land. The two collections of $H$. verticillatus are the only two accessions in the current USDA-ARS seedbank. According to a recent study, despite the fact that only three sites of this species are currently known, there is considerable genetic variation between these populations (Ellis et al., 2006). The study also presents molecular evidence to confirm that $H$. verticillatus is a valid species and not a hybrid between $H$. eggertii and $H$. angustifolius or between $H$. grosseserratus and $H$. angustifolius.

While our primary objective on this trip was to collect the four species mentioned above, this southeastern part of the US is extremely rich in Helianthus species, with at least 27 other species recorded (Rogers et al., 1982; Weakley, 2006). During the trip we also made four collections of three other species: H. angustifolius, H. atrorubens, and H. smithii. Collection site and seed information for these other species is found in Table 2. 


\section{CONCLUSIONS}

The three target species, H. eggertii, $H$. porteri, and $H$. verticillatus, are all restricted geographically, they exist as relatively few populations, and in one case (H. porteri) endemic to a unique habitat. Helianthus eggertii was listed by the USFWS and protected by federal regulations. According to federal guidelines (USFWS, 2005), a species is considered to be endangered if "it is in danger that it will become extinct throughout all or a significant portion of its range," while the definition of a "threatened" species is one that is "likely to become endangered in the foreseeable future." Helianthus eggertii was proposed for "threatened" status in 1994 and listed as such in 1997. However, due to research both to manage existing populations of $H$. eggertii and surveys to document additional populations, the threatened classification was removed from $H$. eggertii as of August, 2005. Distribution of $H$. verticillatus seed is not restricted by the USFWS as this species is currently a "candidate" for listing, and not formally considered threatened or endangered (USFWS, 2002).

The optimal habitat for $H$. eggertii is dry, open areas within forests. While this habitat type can be artificially maintained in some instances, such as the AEDC site in TN for $H$. eggertii, it is less feasible to manage habitats for plants in instances where rare plants occur on private land. However, where this species occurs on roadsides or in power line right-of-ways, management practices have been devised which both help plant survival and address the needs of those sites. Thus, when there is a sizeable population of $H$. eggertii on a highway roadside, the state highway department does not mow that portion of the roadside until after November 15, which allows seed maturation and population stability. Likewise, utility companies are managing woody brush under power lines by mechanical pruning and without herbicides, late in the growing season to minimize damage to rare herbaceous plants.

We have succeeded in collecting a reasonable number of populations of $H$. eggertii and $H$. porteri, which hopefully encompass a wide portion of the genetic diversity of those species. It would be wise to collect seeds from additional populations of $H$. verticillatus since only two populations were sampled.

This exploration addressed a specific need of the USDA-ARS sunflower collection of obtaining seed of species previously not adequately represented (Table 1). Subsequent collections in 2003 to 2006 have targeted additional under-represented species, such as $H$. californicus, $H$. pumilus, $H$. cusickii, and $H$. resinosus. We anticipate future trips will target the remaining species that have no or few accessions in the seed collection, such as $H$. agrestis, H. arizonensis, H. glaucophyllus, $H$. laciniatus, $H$. longifolius, $H$. occidentalis spp. occidentalis, and others. 


\section{ACKNOWLEDGEMENTS}

The authors would like to thank several local botanists who not only supplied us with information on the exact locations of many Helianthus populations, but also accompanied us for portions of our exploration. These individuals include James Allison and Tom Patrick, botanists with the Georgia Natural Heritage Program (H. verticillatus and H. porteri); Claude Bailey, botanist with the Tennessee Department of Environment and Conservation (H. verticillatus); Kevin Fitch, contract botanist managing $H$. eggertii populations on the Arnold Engineering Development Center (US Air Force Base); Patrick McMillan, herbarium curator at Clemson University (H. eggertii), and James Matthews, retired botanist from the University of North Carolina-Charlotte, who helped with several species.

\section{REFERENCES}

Ellis, J.R., Pashley, C.H., Burke, J.M. and McCauley, D.E., 2006. High genetic diversity in a rare and endangered sunflower as compared to a common congener. Mol. Ecol. 15:23452355.

Environmental Systems Research Institute (ESRI), 2004. ArcGIS 9.0. Redlands, CA. USA.

Jones, R.L., 1994. The status of Helianthus eggertii Small in the southeastern United States. Castanea 59:319-330.

Matthews, J.F., Allison, J.R., Ware, R.T. and Nordman, C., 2002. Helianthus verticillatus Small rediscovered and redescribed. Castanea $67: 13-24$.

McVaugh, R., 1943. The vegetation of the granite flat-rocks of the southeastern United States. Ecol. Monographs. 13:120-166.

Mellinger, C.A., 1972. Ecological life cycle of Viguiera porteri and factors responsible for its endemism to granite outcrops of Georgia and Alabama. Ph.D. Dissertation. Univ. North Carolina, Chapel Hill, NC., pp.107.

Murdy, W.H. and Brown Carter, M.E., 2000. Guide to the Plants of Granite Outcrops. U. Georgia Press, Athens., pp. 106.

Pruski, J., 1998. Helianthus porteri (A. Gray) Pruski (Compositae), a new combination validated for the Confederate daisy. Castanea 63:74-75.

Rogers, C.E., Thompson, T.E. and Seiler, G.J., 1982. Sunflower Species of the United States. Nat. Sunflower Assoc., Bismarck, ND., pp. 75.

Schilling, E.E., 2006. Helianthus. In: Flora of North America North of Mexico. New York and Oxford. 21:141-169. (Available on-line at http://www.efloras.org/\%20florataxon.aspx?\%20flora_\%20id=1\&taxon_id=114871).

Seiler, G.J. and Gulya, T.J., 2004. Exploration for wild Helianthus species in North America: Challenges and opportunities in the search for global treasures. Proc. $16^{\text {th }}$ Int. Sunflower Conference, August 29-September 2, 2004, Fargo, ND. 1:43-68.

Shure, D.J. and Ragsdale, H.L., 1977. Patterns of primary succession on granite outcrop surfaces. Ecology 58:993-1006.

Small, J.K. 1898. Studies in the botany of the southeastern United States -XIV. Hitherto undecided species. Bull. Torr. Bot. Club 25:465-482.

U.S. Fish and Wildlife Service (USFWS), 2002. Candidate and listing priority assignment form for Helianthus verticillatus, pp. 9. (Available at: http://ecos.fws.gov/docs/candforms_pdf/ r4/helver.pdf).

U.S. Fish and Wildlife Service (USFWS). 2005. Listing a species as threatened or endangered. Endangered Species Program 703/358 2105, pp. 2. (Available at: http://www.fws.gov/ Endangered/listing/listing.pdf). 
Weakley, A.S., 2006. Flora of the Carolinas, Virginia, Georgia and surrounding areas. (Working draft as of 9 August, 2006), pp. 1014. (Available at: http://herbarium.unc.edu/weakleysflora.pdf).

White, D.L. and Ratzlaff, J.A., 1999. Recovery plan for Helianthus eggertii Small (Eggert's sunflower). USFWS, Atlanta, GA. pp. 40.

\title{
BÚSQUEDA Y RECOLECCIÓN DE LAS ESPECIES RARAS DEL GÉNERO Helianthus EN LA PARTE SURESTE DE LOS EE.UU.
}

\author{
RESUMEN
}

La expedición de diez días de duración, durante la cual fue recorrido $4600 \mathrm{~km}$ en los estados sureste de los EE.UU., Tenesi, Carolina del Norte, Carolina del Sur, Georgia y Alabama, fue emprendida en mes de octubre de 2003. El objetivo principal fue encontrar las poblaciones de la especie Helianthus eggertii, que en aquel entonces estaba en el listado de las especies en peligro de extinción de la USDI, Agencia de Pesca y el Mundo Salvaje, y de la especie $H$. verticillatus, que fue candidato para la inscripción en el listado de las especies en peligro de extinció. Mientras tanto, Helianthus eggertii fue quitada del listado (en agosto de 2005). El objetivo adicional fue la recolección de semillas de la especie $H$. porteri, una especie que ha sido preclasificada de la especie Viguiera porteri, que aparece como endémica en las perturberancias de granito de las montañas en Georgia. Fue recolectado 27 poblaciones de tres especies susodichas tanto como de tres especies adicionales, $H$. angustifolius, $H$. atrorubens y $H$. smithii. La semilla se confirió a custodia en la Estación de Introducción de Plantas USDA-ARS, en la región septentrional-central, Eims, Iowa (NCRPIS); 24 de 27 de las muestras recolectadas están listas para el intercambio. Tres especies "de meta" están representadas a través de 13 muestras de la especie $H$. eggertii, 8 muestras de la especie $H$. porteri y 2 muestras de la especie $H$. verticillatus; Ninguna de dichas tres especies, hasta el momento, ha sido presentada en la colección de girasol de NCRPIS. La puesta en disposición de la semilla de dichas tres especies a los investigadores a lo largo del mundo, permitirá la investigación de estas tres especies del género Helianthus de dar la contribución por las características útiles de girasol cultivado. Los datos sobre la colección completa, fueron introducidos en la Red USDA-ARS GRIN (Germplasm Resource Information Network), que puede encontrarse en Internet (www.ars-grin.gov).

\section{RECHERCHE ET CUEILLETTE D'ESPÈCES RARES D'HELIANTHUS dans le sud-est des Etats-Unis

\author{
RÉSUMÉ
}

Un voyage de dix jours et de $4600 \mathrm{~km}$ dans quelques états du sud-est des États-Unis (Tennessee, Caroline du Nord, Caroline du Sud, Georgia et Alabama) a été entrepris en octobre 2003. Le but principal était de trouver des populations de l'espèce Helianthus eggerti qui était à cette époque sur la liste de l'Agence de protection des espèces de faune et de flore sauvages menacées (USDI), et des populations de l'espèce $H$. verticillatus qui était susceptible d'y être inscrite. Depuis, l'espèce Helianthus eggertii a été retirée de la liste (en août 2005). Le second but de la recherche était de recueillir des graines de H. porteri, une espèce reclassée de l'espèce Viguiera porteri qui apparaît 
comme endémique sur les affleurements de granit en Georgia. Vingt-sept populations des trois espèces mentionnées ainsi que trois espèces supplémentaires, $H$. angustifolius, $H$. atrorubens et $H$. smithii ont été récoltées. Les graines ont té déposées à la Station pour l'introduction des plantes USDA-ARS, région nord-centre, Ames, Iowa (NCRPIS) ; 24 des 27 échantillons recueillis sont prêts à être distribués. Les trois espèces "ciblées" sont représentées par 13 échantillons de l'espèce $H$. eggertii, 8 de l'espèce $H$. porteri et 2 de l'espèce H. verticillatus ; jusqu'à maintenant aucune de ces trois espèces n'avait été présentée dans la collection NCRPIS. La disponibilité de ces trois espèces permettra aux scientifiques du monde entier d'examiner le potentiel de ces trois espèces du genre Helianthus et de contribuer ainsi à l'exploitation des caractéristiques utiles de ces espèces Helianthus sauvages dans la culture du tournesol cultivé. Les données sur la collection complète ont été introduites dans le réseau USDA-ARS GRIN (Germplasm Resource Information Network) qu'on peut trouver sur la toile http://www.ars-grin.gov). 